\title{
EFEKTIFITAS WAKTU PELAKSANAAN PEKERJAAN REKONSTRUKSI JALAN WOLO - BATAS KOTA KOLAKA - RATE RATE
}

\author{
Ahmad $^{1)}$, Irwan Lakawa ${ }^{2)}$, dan La Ode Musa Rachmat ${ }^{3}$ \\ ${ }^{1}$ Mahasiswa Teknik Sipil, Fakultas teknik, Universitas Sulawesi Tenggara \\ email: mad64214@gmail.com \\ ${ }^{2}$ Dosen, Jurusan Teknik Sipil, Fakultas Teknik, Universitas Sulawesi Tenggara \\ email: ironelakawa@gmail.com \\ ${ }^{3}$ Dosen, Jurusan Teknik Sipil, Fakultas Teknik, Universitas Sulawesi Tenggara \\ email: laodemusarachmat@gmail.com
}

\begin{abstract}
By analyzing the implementation of this project work is expected to know the comparison between the plan and the realization, the effectiveness of the time executor and factors affecting the effectiveness of implementation on road reconstruction work. The medhod used in this research is to take data in the form of curve $\mathrm{S}$, RAB, back up data, weekly report, montly report and questonnaire data for factors that influence the implementation of extreme weather factors, coordination factor between agencies, factors of delay in material testing, experience of executor and tool availability factor with analysis using SPSS mean rank aplication.

Based on the result of reviewing and data analyzing, the time that occurs in the implementation of the road reconstruction work has been delayed due to get minus deviation value, than is in February - 0,225\%, March 4,855 \%, April -10,118 \%, May - 20,606 \%, June - 37,379 \%, July - 57,111 \%, August - 55,379 \% .

Data for the value of the effectiveness of work on aggregate class B in April 0,4 months Mei 0,87, June 0,90 , July 0,87 , August 0,87 . Aggregate of class A in May 0,13, June 0,17 , month of July 0,35 , month of August 0,90 and work of asphalting AC-BC its effectiveness value is 0,4

The data for factor affecting effectveness of implementation based on mean rank analysis ie extreme weather 3,0, coordination between intances 3,30, material testing delay 2,90, execution experience 2,90, availability of tools $2,90 \mathrm{~s}$
\end{abstract}

Keywords: Time Management, Effectiveness

\section{ABSTRAK}

Dengan menganalisa efektifitas pelaksanaan pekerjaan proyek ini diharapkan dapat mengetahui perbandingan antara rencana dan realisasi, efektifitas waktu pelaksanaan dan faktor - faktor yang mempengaruhi efektifitas pelaksanaan pada pekerjaan rekonstruksi jalan. Metode yang di pakai pada penelitian ini adalah mengambil data berupa kurva S, RAB, back up data, laporan mingguan, laporan bulanan dan data kuisioner untuk faktor - faktor yang mempengaruhi pelaksanaan yaitu faktor cuaca ekstrim, faktor kordinasi antara instansi, faktor keterlambatan pengujian bahan, faktor pengalaman pelaksana dan faktor ketersediaan alat dengan analisis menggunakan aplikasi SPSS mean rank.

Berdasarkan hasil pembahasan dan analisa data bahwa analisa waktu yang terjadi pada pelaksanaan pekerjaan rekonstruksi jalan mengalami keterlambatan karena mendapatkan nilai deviasi minus, yaitu bulan Februari - 0,225 \%, Maret - 4,855 \%, April - 10,118 \%, Mei - 20,606 \%, Juni - 37,359 \%, Juli - 57,111\%, Agustus $-55,379 \%$.

Data untuk nilai efektifitas pekerjaan pada agregat kelas B bulan April adalah 0,4 bulan Mei 0,87, bulan Juni 0,9, bulan Juli 0,87 dan bulan Agustus 0,87. Aggregat kelas A bulan Mei 0,13, bulan Juni 0,17, bulan Juli 0,35, bulan Agustus 0,90 dan pekerjaan pengaspalan AC-BC nilai efektifitasnya adalah 0,4

Data untuk faktor yang mempengaruhi efektifitas kerja berdasarkan analisis mean rank yaitu cuaca ekstrim 3,0, kordinasi antara instansi 3,30, keterlambatan pengujian bahan 2,90, pengalaman pelaksana 2,90, ketersediaan alat 2,90

Kata Kunci : Manajemen Waktu, Efektifitas 


\section{PENDAHULUAN}

Kolak merupakan daerah Sulawesi Teng gara, akses darat yang menghubungkan wilayah Sulawesi Tenggara dengan Sulawesi Selatan, menjadi penghubung Kolaka dengan Kabupaten Kolaka Timur, Kabupaten Konawe dan Kota Kendari. Jalan Wolo - Batas Kolaka berjarak sekitar 60 kilo meter (KM 231+000 - 171+000), kondisi jalan sebagian sudah di perluas terutama jalan di Kecamatan Samaturu Batas Kota Kolaka dengan jarak sekitar 22 kilo meter (KM 193+000 - 171+000) sudah dilebarkan,dengan adanya perluasan jalan dan akses jalan yang memadai tentunya akan meningkatkan pertumbuhan perekonomian di Daerah tersebut.

Kegiatan suatu proyek pembangunan dapat diartikan sebagai satu kegiatan yang sementara berlangsung dalam jangka waktu terbatas. Perencanaan suatu proyek dapat diartikan sebagai pemberi pegangan bagi pelaksana mengenai alokasi sumber daya untuk melaksanakan kegiatan dan memastikan penggunaan sumber daya secara efektif dan efisien (Abrar, 2009)

Efektifitas adalah perbandingan antara input dan output dalam berbagai aktifitas kegiatan sampai dengan pencapaia $\mathrm{n}$ tujuan terpenuhi yang bisa dari berupa banyaknya kuantitas dan kualitas hasil kerja, maupun batas waktu yang sudah di tetapkan atau ditargetkan sebelumnya( Mahmudi, 2005)

Manajemen proyek merupakan suatu tata cara mengorganisir dan mengelolaan sumber penghasilan yang penting untuk menyelesaikan proyek dari awal sampai terselesaikanya proyek tersebut. Manaje men proyek dapat diterapkan pada jenis proyek apapun, dan dipakai secara luas untuk menyelesaikan proyek yang besar dan kompleks. Fokus utama manajemen proyek adalah pencapaian semua tujuan akhir proyek dengan segala batasan yang ada, waktu dan dana yang tersedia. Manajemen proyek sangat penting dalam suatu pekerjaan di lapangan, manjemen proyek berguna untuk meminimalisir agar tidak terajadi kegagalan pada proyek tersebut, maka dari itu pelaksanaan proyek harus sesuai dengan perencanaan sebelumnya.

Pelayanan jasa yang dapat mengendalik an tuntutan utama mengenai tingkat keakuratan kualitas, efisiensi pembiayaan dan ketepatan waktu, masih dan sangat diperlukan. Untuk keluar dari masalah tersebut adalah pelayanan manajemen konstruksi yang berfungsi sebagai alat bantu yang mampu mengendalikan seluruh proses dalam proyek sehingga akan menca pai hasil yang optimal dipandang dari segi triple constraint yaitu waktu (jadwal), biaya (anggaran) dan mutu (kualitas). Waktu atau jadwal proyek harus dikerjakan sesuai dengan kurun waktu dan tanggal akhir yang telah ditentukan. dan anggaran proyek harus diselesaikan dengan tepat waktu.

Biaya yang tidak melebihi anggaran. Selain itu, mutu produk atau hasil kegiatan proyek harus memenuhi tugas yang dimaksudkan atau sering disebut sebagai fit for intended use. Dengan manaje men waktu, biaya dan mutu pelaksanaan yang baik, maka resiko sebuah proyek akan mengalami keterlambatan semakin kecil. Secara langsung hal tersebut akan mengurangi pembengkakan biaya proyek, serta pada akhirnya keuntungan tersendiri bagi para kontraktor sebagai pelaksanaan proyek. Sehingga sistem pengendalian proyek sangat perlu diperhitungkan secara matang karena hal ini berhubungan dengan biaya yang digunakan, waktu yang diperluk an serta mutu yang dihasilkan.

\section{Rumusan Masalah}

Berdasarkan latar belakang yang telah di uraikan, maka rumusan masalah yang akan di teliti dari permasalahan tersebut adalah sebagai berikut :

1) Seberapa besar deviasi pelaksanaan pekerjaan Rekonstruksi Jalan Wolo - Batas Kota Kolaka - Rate-Rete. ?

2) Seberapa besar efektifiatas waktu pelaksanaan pekerjaan Rekonstruksi Jalan Wolo - Batas Kota Kolaka Rate-Rate? 
3) Faktor apa saja yang mempengaruhi efektifitas waktu pelaksanaan pekerjaan Rekonstruksi Jalan Wolo - Batas Kota Kolaka - Rate-Rate ?

\section{Tujuan Peneliitian}

Penelitian ini bertujuan :

1) Menganalisis deviasi pelaksanaan pekerjaan Rekonstruksi Jalan Wolo - Batas Kota Kolaka - Rate-Rate.

2) Menganalisis efektifitas waktu pelak sanaan pekerjaan Rekonstruksi Jalan Wolo - Batas Kota Kolaka - RateRate.

3) Menganalisis faktor yang mempengaruhi efektifitas waktu pelaksanaan pekerjaan Rekonstruksi Jalan Wolo - Batas Kota Kolaka Rate-Rate.

\section{Ruang Lingkup Bahasan}

Untuk mempermudah pembahasan penulis membatasi masalah sebagai berikut:

1) Membahas mengenai rencana dan re alisasi pekerjan Rekonstruksi Jalan Wolo - Batas Kota Kolaka - RateRate

2) Membahas mengenai waktu efektifitas pekerjaan aggregat kelas B, kelas A dan pekerjaan pengaspalan AC-BC pada pelaksanaan pekerjaan Rekonstruksi Jalan Wolo - Batas Kota Kolaka Rate-Rete.

3) Membahas mengenai faktor-faktor apa saja yang mempengaruhi efektifitas pelaksanaan pekerjaan Rekonstruksi Jalan Wolo - Batas Kota Kolaka - Rate-Rete.

\section{TINJAUAN PUSTAKA}

\section{Kinerja Pelaksanaan Proyek}

Agar proyek dapat terlaksana sesuai dengan sasaran, maka perlu diperhatikan kinerja dari proyek tersebut. Untuk melihat apakah kinerja proyek telah sesuai dengan sasaran, perlu diamati anggaran, jadwal dan mutu. Anggaran biasanya diamati dari segi biaya, jadwal diamati dari segi waktu, sedangkan mutu diamati dari segi kinerja biaya dan waktu. Kadang-kadang, dalam pelaksanaan suatu proyek, pihak kontrktor kurang memperhatikan kinerja pelaksanaan proyek. Padahal kinerja pelaksanaan suatu proyek akan menentukan apakah proyek tersebut akan tepat sasaran atau tidak. Kinerja proyek sangat diperlukan untuk mengetahui efisiensi dan evektifitas pelaksa naannya sehingga permasalahan yang timbul dalam pengelolaan proyek dapat diidentifikasi dan dicari solusinya serta dijadikan pelajaran untuk pelaksanaan proyek serupa berikutnya (Anonim, 2013)

Kinerja proyek dapat diukur dari indikator kinerja biaya, mutu, waktu, serta keselamatan kerja dengan merencanakan secara cermat, teliti dan terpadu seluruh alokasi sumberdaya manusia, peralatan, material, serta biaya yang sesuai dengan kebutuhan yang diperlukan.Semua itu diselaraskan dengan sasaran dan tujuan proyek.

Agar hasilnya efektif dan efisien,standar kinerja proyek selama proses berlangsung harus ditetapkan sedetail dan seakurat mung kin untuk meminimalkan penyimpangan, biaya, mutu, dan waktu, dan keselamatan merupakan tolak ukur kinerja proyek dalam mencapai sasaran dan tujuan proyek. Optimasi pencapaian paling penting adalah keselamatan kerja, karena bila faktor ini dia baikan dapat mempenga ruhi kinerja biaya, mutu, dan waktu, yang lebih jauh dapat mengakibatkan kerugian materi dan jiwa yang besar.

\section{Prinsip dan Dasar Manajemen Proyek}

Dari kalangan para ahli belum terdapat adanya konsesus keseragaman dalam membagi jumlah fungsi manajemen. Tetapi pada umumnya kita dapat membagi fungsi manajemen itu dalam defenisi yang di uraikan dengan singkatan POMC (Planning, Organizing and Staffing, Motivating, Controlling) (Soeharto, 1999)

1. Perencanaan (Planning) : mempunyai tiga arti, yaitu :

a) Pengambilan keputusan (decision making) 
b) Memikirkan secara mendalam untuk memutuskan apa yang harus diperbuat
c) Menetapkan sasaran dan menjabarkan cara mencapai sasaran- sasaran tersebut

2. Pengaturan dan Penyediaan Staff (Organizing and Staffing)

Dalam struktur organisasi ada beberapa hal yang perlu di perhatikan, antara lain :

1) Hubugan antara bawahan dan atasan harus jelas, komunikasi timbal balik harus terpelihara.

2) Tugas disertai pemberian wewenang yang berimbang dengan tanggung jawab (responsibility) yang dipikul

3) Tanggung gugat (accounbility) terhadap atasan juga harus ada.

4) Uraian tugas pekerjaan untuk staff dan pimpinan perlu dijabarkan dengan jelas dan kongkrit (job discription)

5) Makin tinggi jenjang manajerial makin sedikit bawahannya, dan sebaliknya makin kebawah makin banyak orang yang dibawahinya (struktur piramida)

3. Menggerakan (Motivating)

Menggerakan yang di maksud adalah kemampuan dari seorang manager proyek untuk memberikan alasan kepada bawahannya untuk pengembangan sumber daya manusia dan bimbingan kerja (yang berperan di sini adalah faktor leadership/jiwa kepemimpinan). Pemimpin proyek selalu berusaha agar para bawahannya menjadi ahli dalam bidang pekerjaannya dan terampil dalam bidang manajemennya.Motivasi merupakan kegiat an yang mengakibatkan, menyalurkan dan memeliharaperilaku manusia dan motivasi ini merupakan suatu subyek yang penting bagi manager, karena menurut devenisi manager harus bekerja dengan melaui orang lain, maka manager perlu memahami orang-orang yang berperilaku tertentu agar dapat mepengaruhi untuk bekerja sesuai dengan yang di inginkan organisasi.

Faktor Motivasi yang perlu diciptakan oleh seseorang manager proyek, meliputi: (Soeharto, 1995 dalam Aldilan 2016)
1) Komunikasi timbal balik antara atasan dan bawahan, sehingga tercipta iklim kerja yang berkesinambungan.

2) Diciptakan unsur partisiasi dalam memecahkan masalah dan pengambilan keputusan.

3) Metoda, program kerja yang mantap dan jelas.

4) Berorientasi kepada hasil pekerjaan.

5) Delegasi pekerjaan harus disertai tanggung jawab yang jelas, limitasi wewenag untuk dapat mengambil keputusan serta kriteria tentang hasil pekerjaan.

6) Menghargai bawahan yang berprestasi dan ciptakan disiplin yang tegas.

7) Menciptakan suasana agar bawahan memilki kemampuan untk bekerja sama secara kelompok (team work).

\section{Pengontrolan (Controlling)}

Pengontrolan dilakukan untuk melihat Perkembangan pekerjaan, apakah sesuai dengan rencana, atau apakah ada penyimpa ngan? Pengontrolan bisa dilakukan dari laporan dan dari pengecekkan lapangan, dan dari keduanya dilakukan pencocokan mana yang lebih aktual mendeteksi kondisi nyata. Tujuan pengontrolan tidak mecari kesalahan orang, melainkan untuk menjaga dan melihat apakah hasil pekerjaan sesuai dengan recana atau tidak, sesuai rencana yang dimaksud adalah kegiatan proyek dapat dimulai, dilaksanakan dan diselesai kan menurut jadwal yang telah ditentukan, budget yang disediakan, mutu pekerjaan yang di tetapkan dan sumber daya alam serta sumber daya manusia yang tersedia.

5. Langkah dalam melakukan fungsi kontrol

a) Adanya prestasi standard sebagai tolak ukur

b) Mengukur hasil prestasi pekerjaan

c) Membandingkan dan mengevaluasi hasil prestasi aktual dengan standard prestasi yang diharapkan 
d) Melakukan tindakan koreksi, bilamana standard prestasi tidak tercapai.

Secara spesifik konsep manajemen adalah merupakan suatu proses, dimana didalamnya diberikan input dan diharapkan manajemen dapat menghasilkan output sesuai sasaran sebagaimana yang ditetapkan. Input dalam proses manajemen terdiri dari bermacam-macam sumber daya (resource), seperti:
a) Money (Uang)
b) Material (Bahan)
c) Machine (Peralatan)
d) Man Power (Tenaga Manusia)
e) Market (Pasar)
f) Methode (Metode) serta Information (Inormasi)
g) Space (Ruang) dan Time (Waktu)

\section{Sistem Manajemen Proyek}

Sisitem manajemen proyek disusun dan dijabarakan menjadi seperangkat pengertian alat dan petunjuk tatacara yang mudah untuk dilaksanakan sedemikan rupa sehingga (Djojowirono, 2005)

1) Mampu menghubungkan dan menjembatani kesenjangan persepsi diantara para perencana dan pelaksana, sehingga kesemuanya mempunyai satu kerangka konsep yang sama tentang kriteria keberhasilan suatu proyek.

2) Dapat memberikan kesamaan bahasa yang sekaligus memadukan tertib teknis dan sosial, yang dapat diterapkan pada setiap proyek dengan cara sederhana, jelas, sitematis dan efisien.

3) Mampu mewujudkan suatu bentuk kerjasama dan koordinasi antar satuan

organisasi pelaksanaan sehingga ter wujud suatu semangat bersama untuk

merencanakan proyek secara lebih terperinci dan cukup cermat dalam mengantisipasi masalahmasalah yang akan timbul dalam pelaksanaan.

\section{Manajemen Biaya \\ Kinerja Biaya}

Seluruh urutan kegiatan proyek perlu memiliki standar kinerja biaya proyek yang dibuat dengan akurat dengan cara membuat format perencanaan seperti di bawah ini (Barrie 1995 dalam Sriyatno 2005)

a) Kurva S, selain daptat mengetauhui proses waktu proyek, kurva $\mathrm{S}$ berguna juga untuk mengendalikan kinerja biaya, hal ini ditujuakandari bobot pengeluaran kumulatif masing-masing kegiatan yang dapat dikontrol dengan membandingkan dengan baseline periode tertentu sesuai dengan kemajuan aktual proyek.

b) Diagram Cash Flow, diagram yang menunjukan rencana aliran pengeluaran dan pemasukan biaya selama proyek berlangsung. Diagram ini diharapkan dapat mengendalikan keseluruhan biaya proyek secara detail sehingga tidak mengganggu keseimbangan kas proyek.

c) Kurva Earned Value, yang menyatakan nilai uang yang telah dikeluarkan pada baseline tertentu sesuai dengan kemajuan actual proyek. Bila ada indikasi biaya yang dikeluarkan melebihi rencana, maka biaya ini dikoreksi dengan melakukan penjadwalan ulang dan meramalkan seberapa besar biaya yang harus dikeluarkan sampai akhir proyek karena penyimpangan tersebut.

d) Balance sheet, yang menyatakan besarnya aktiva dan pasiva keuangan perusahaan selama periode satu tahun dengan keseluruhan proyek yang telah dikerjakan beserta asset-aset yang dimiliki perusahaan. Keempat hal tersebut dibuat dalam laporan periodik dengan maksud agar dari waktu dapat dievaluasi serta dikendalikan dan menjadi rujukan dalam membuat keputusan terkait dengan tindakan koreksi bila terjadi penyimpangan

\section{Perkiraan Biaya}

Perkiraan biaya melibatkan pendekatan (perkiraan) dari biaya sumber daya yang 
dibutuhkan untuk menyelesaikan kegiatan proyek. Dalam aproksimasi biaya, estimator menganggap penyebab variasi estimasi akhir untuk tujuan lebih baik mengelola proyek. Ketika sebuah proyek dilakukan di bawah kontrak, perawatan harus dilakukan untuk membedakan perkiraan biaya dari harga.

\section{Anggaran Biaya}

Penganggaran Biaya melibatkan pengalokasian perkiraan biaya keseluruhan untuk kegiatan individu atau bekerja untuk mendirikan sebuah paket biaya dasar untuk mengukur kinerja proyek. Realitas dapat mendikte bahwa perkiraan yang dilakukan setelah persetujuan anggaran adalah disediakan, namun perkiraan harus dilakukan sebelum permintaan anggaran.

\section{Hasil Dari Anggaran Biaya}

Baseline biaya anggaran bertahap waktu yang akan digunakan untuk mengukur dan memonitor kinerja biaya pada proyek tersebut. Hal ini dikembangkan oleh penjumlahan estimasi biaya dengan periode dan biasanya ditampilkan dalam bentuk kurva-S, banyak proyek, khususnya yang lebih besar, mungkin memiliki beberapa data dasar untuk biaya aspek yang berbeda ukuran kinerja biaya.

\section{Manajemen Waktu Kinerja Waktu}

Faktor - faktor yang mempengaruhi efektifitas pelaksanaan menggunakan data Standar kinerja waktu ditentukan dengan merujuk seluruh tahapan kegiatan proyek beserta durasi dan pengguanaan sumber daya. Dari semua informasi dan data yang diperoleh, dilakukan proses penjadwalan sehingga akan ada output berupa formatformat laporan lengkap mengenai indikator progress waktu.

Adapun persamaan yang digunakan ada lah sebagai berikut:

$$
\text { a) Bobot }=\frac{\text { Harga Item Peksrjaan }}{\text { Total Harga Pekerjaan }} \times 100 \%
$$

a) Kebutuhan Tonase $=P \times L \times$ tebal $x$ berat jenis............. 22

b) Efektifitas Waktu Kerja

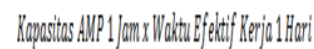

$$
=\frac{\text { Tonase }}{\text { Waktu Ef ektif Kerja } 1 \text { Hari }} \ldots \ldots \ldots \ldots \ldots . \ldots 2.4
$$

c) kuisioner kemudian diolah menggunakan aplikasi SPSS.

d) Faktor - faktor yang mempengaruhi efektifitas pelaksanaan mengguna kan data kuisioner kemudian diolah menggunakan aplikasi SPSS.

\section{Kurva S}

Menurut (Barrie 1995 dalam Aldilan 2016), bentuk kurva $S$ berasal dari pemaduan kemajuan setiap tahun waktu untuk mendapatkan kemajuan kumulatif yang digunakan dalam pemantauan pekerjaan. Ukuran kemajuan dititikberatkan pada prestasi kerja dan biaya.Sumbu $\mathrm{X}$ menunjukan skala waktu, sedangkan pada sumbu Y merupakan skala biaya atau prestasi kerja.Pada sebagian besar proyek, pengeluaran dari sumber daya untuk setiap satuan waktu condong berjalan lambat, berkembang ke puncak, kemudian berangsur-angsur berkurang bila mendekati ujung akhir.Karena itulah kemajuan sering tergambar seperti huruf $\mathrm{S}$.

\section{Laporan Kemajuan}

Laporan minggun merupakan sebuah pertanggung jawaban dalam bentuk tertulis mengenai kegiatan yang sudah dijalankan s elama satu minggu untuk kemudian dituangkan dalam bentuk tertulis. Laporan mingguan ini dibuat oleh kontraktor atau konsultan pengawas untuk diberikan kepada owner atau pemilik proyek. Dengan adanya laporan ini maka proses pelaksanaan pekerjaan dapat diarsipkan.

Sebelum membuat laporan mingguan proyek maka terlebih dahulu dibuat laporan harian proyek yang merupakan laporan per hari mengenai pekerjaan yang sedang dilaksanakan, dari 7 laporan harian proyek tersebut maka dapat dibuat rekap selama 
satu minggu dalam bentuk laporan mingguan.

Laporan mingguan proyek kontraktor berisi berbagai data pekerjaan yang antara lain sebagai berikut : (Barrie 1995 dalam Aldilan)

1) Nomor laporan mingguan

2) Nama kontraktor dan nama konsultan

3) Judul laporan

4) Periode tanggal dan waktu laporan

5) Jumlah tenaga kerja dan keahlian masing-masing tenaga kerja selama satu minggu bekerja di proyek, dapat dibuat dalam bentuk mengisi jumlah absen harian.

6) Pekerjaan yang dilaksanakan dibuat sejelas mungkin mengenai lokasi pekerjaan, nama pekerjaan dan besarnya volume progress yang sudah diselesaikan selama satu minggu penuh.

7) Bahan atau material yang digunakan.

8) Alat kerja yang dipakai untuk melaksanakan pekerjaan.

9) Laporan curah hujan atau cuaca selama proses pelaksanaan proyek berlangsung satu minggu, laporan cuaca ini dapat digunakan kontraktor sebagai alasan keterlamba tan kerja untuk menghindari denda keterlam batan pekerjaan dikemudian hari.

10) Form persetujuan konsultan pengawas atau manajemen konstruksi.

11) Form pengajuan kontraktor atau yang membuat laporan mingguan proyek.

12) Lampiran lampiran foto pelaksanaan proyek maupun hasil akhir kegiatan.

13) Serta data-data lain menyesuaikan kebutuhan dan permintaan pemilik proyek.

Masing-masing perusahaan kontraktor atau konsultan pengawas biasanya mempunyai standar formulir laporan mingguan tersendir untuk digunakan disetiap pekerjaan proyek. Dari laporan mingguan proyek ini kemudian didapat rekap dalam bentuk bulan selama 1 bulan penuh.

Dengan demikian, setiap selesai perekapan laporan kemajuan oleh pihak kontraktor atau konsultan pengawas, laporan tersebut dapat dikirim dan di lakukan pengimputan pada program prima vera project planner. Dengan kata lain,peng guna software tidak harus berada dilokasi pengerjaan untuk melakukan pelaporan? reporting ke dalam software primavera project planner.

\section{Durasi Dipercepatnya Proyek}

Pada awal saat proyek direncanakan, durasi aktivitas direncanakan dengan sumber daya yang tersedia (sumber daya normal). Bila kemudian hari penyelesaian pekerjaan ingin dipercepat karena alasan tertentu seperti penambahan sumber daya yang mengakibatkan pertambahan biaya langsung, ada beberapa cara yang dapat dilakukan, yaitu :

a) Penambahan jam kerja (lembur)

Bila dokumen kontrak menurut jadwal kerja yang singkat, maka harus dipertimban gkan kemungkinan program kerja lembur dalam upaya memenuhi target waktu. Kerja lembur dapat dilakukan dengan menambahkan jam kerja (lembur), maka perlu dievaluasi dampak dari jadwal terhadap pembiayaan. Upah tenaga kerja untuk penambahan jam kerja lembur adalah sebesar 1,5 sampai 2 upah kerja normal. Hal ini disebabkan karena produktivitas kerja lembur tidak sama dengan produktivitas kerja normal.

b) Pembagian Giliran Kerja.

Jika tenaga kerja cukup tersedia untuk memenuhi kebutuhan mungkin dapat diatur dengan cara bergantian yaitu unit pekerja giliran sore sampai malam. Untuk menjaga agar produktivitas ini tetap maka giliran kerja diprioritaskan dan diusahakan agar seseorang pekerja dapat bekerja sama dengan timnya.

c) Penambahan Tenaga Kerja. 
Penambahan tenaga kerja dimaksudkan sebagai penambahan jumlah pekerja dalam satu unit pekerja untuk melaksanakan suatu aktivitas tampa menambahkan jam kerja, tetapi penambahan tenaga kerja yang optimum akan meningkatkan produktivitas kerja, tetapi penambahan yang terlalu banyak justru menurunkan produktivitas kerja.

d) Penambahan atau Pergantian Peralatan.

Penambahan atau pergantian peralatan dimaksudkan untuk menambah produktivi tas kerja, mencegah keletihan kerja yang lebih dan mengurangi jumlah tenaga kerja manusia.

e) Pergantian atau Perbaikan Metode Kerja Pergantiann atau perbaikan metode kerja dilakukan bila metode yang sudah dilakukan terlalu terlambat atau tidak efisien.

f) Konsentrasi Pada Aktivitas Tertentu

Konsentrasi ini berarti penambahan/ pemindahan peralatan pada suatu aktivitas tertentu.

g) Kombinasi dan Alternatif Yang Ada.

Dalam perencanaan, percepatan durasi dapat dilakukan dengan mengkombinasikan alternatf-alternatif yang ada sehingga menghasilkan suatu cara yang sesuai dengan proyek tersebut, terutama pada proyek yang berskala besar dan mempunyai banyak aktifitas.

\section{Faktor Keterlambatan Proyek Dan Analisis \\ Pengertian Keterlambatan Proyek}

Keterlambatan proyek konstruksi berarti bertambahnya waktu pelaksanaan penyelesaian yang telah direncanakan dan tercantum dalam dokumen kontrak. Penyelesaian pekerjaan tidak tepat waktu adalah merupakan kekurangan dari tingkat produktifitas dan sudah tentu kesemuanya ini akan mengakibatkan pemborosan dalam pembiayaan, baik berupa pembiayaan langsung yang dibelanjakan untuk proyek proyek pemerintah, maupun berwujud pembengkakan investasi dan kerugiankerugian pada proyek-proyek swasta.
Peran aktif manajemen merupakan salah satu kunci utama keberhasilan pengelolahan proyek. Pengkajian jadwal proyek diperluk an untuk menentukan langkah perubahan mendasar agar keterlambatan penyelesaian proyek dapat dihindari atau dikurangi.

\section{a. Dampak Keterlambatan}

Keterlambatan proyek akan menimbulkan kerugian pada pihak kontraktor, konsultan, danowner, yaitu :

1. Pihak kontraktor

2. Pihak Konsultan

3. Pihak Owner

\section{b. Penyebab Keterlambatan}

Keterlambatan proyek disebabkan oleh beberapa faktor yang berasal dari Kontraktor,Owner, dan selain kedua belah pihak.

1) Keterlambatan akibat kesalahan Kontraktor, antara lain :

a) Terlambatnya memulai pelaksanaan proyek.

b) Pekerja dan Pelaksana kurang berpengalaman.

c) Terlambat mendatangkan peralatan. d) Mandor yang kurang aktif.

e) Rencana kerja yang kurang baik.

2) Keterlambatan akibat kesalahan Owner

a) Terlambatnyaangsuran pembayaran oleh Kontraktor.

b) Terlambatnya penyedian lahan.

c) Mengadakan perubahan pekerjaan yang besar.

d) Pemilik menugaskan Kontraktor lain untuk mengerjakan proyek tersebut.

3) Keterlambatan yang diakibatkan selain kedua belah pihak diatas, antara lain ;

a) Akibat kebakaran yang bukan kesalahanKontraktor,Konsultan, Owner.

b) Akibat perang, gempa, banjir, ataupun bencana lainnya.

c) Perubahan moneter. 


\section{Rencana Kuisioner Faktor Keterlambatan}

1) Faktor Cuaca Ekstrim
a) Sangat Tidak Berpengaruh (skor 1)
b) Tidak Berpengaruh (skor 2)
c) Cukup Berpengaruh (skor 3)
d) Berpengaruh (skor 4)
e) Sangat Berpengaruh (skor 5)

2) Faktor Kordinasi Antara Instansi
a) Sangat Tidak Berpengaruh (skor 1)
b) Tidak Berpengaruh (skor 2)
c) Cukup Berpengaruh (skor 3)
d) Berpengaruh (slor 4)
e) Sangat Berpengaruh (skor 5)

3) Faktor Keterlambatan Pengujian Bahan
a) Sangat Tidak Berpengaruh (skor 1)
b) Tidak Berpengaruh (skor 2)
c) Cukup Berpengaruh (skor 3)
d) Berpengaruh (skor 4)
e) Sangat Berpengaruh (skor 5)

4) Faktor Pengalaman Pelaksana

a) Sangat Tidak Berpengaruh (skor 1)

b) Tidak Berpengaruh (skor 2)

c) Cukup Berpengaruh (skor 3)

d) Berpengaruh (skor 4)

e) Sangat Berpengaruh (skor 5)

5) Faktor Ketersediaan Alat
a) Sangat Tidak Berpengaruh (sko 1)
b) Tidak Berpengaruh (skor 2)
c) Cukup Berpengaruh (skor 3)
d) Berpengaruh (skor 4)
e) Sangat Berpengaruh (skor 5)

\section{Analisis Faktor Keterlambatan Pengisian Kuisioner}

Pengisian kuisioner dibagikan kepada responden dengan cara diantar langsung oleh peneliti, dengan maksud meminta pihak responden mengisi kuisioner tersebut. Apabila pihak responden cukup sibuk, maka peneliti meninggalkan kuisioner tersebut, kemudian meminta agar diisi langsung oleh kontraktor yang langsung bekerja pada proyek yang dikerjakan dan akan diambil setelah selang beberapa hari.

\section{Pengolahan Data Penelitian}

Setelah seluruh data yang diperoleh melalui kuisioner terkumpul, kemudian diadakan

tahapan berikutnya, yaitu analisis data. Analisis studi ini menggunakan metode kuantitatif, yang dioperasikan dengan menggunakan program SPSS (Statistical Package for the Social

Sciences) untuk mencari beberapa besar faktor - faktor yang berpengaruh terhadap keterlambatan pelaksanaan proyek, dan paling menentukan berdasarkan urutan rangking dalam setiap penelitian.

Langkah untuk menganalisis data pada penelitian ini adalah sebagai berikut:

a) Analisis Responden

Data yang telah diberikan oleh responden dalam kuisioner yang telah disebar, akan diolah dan digunakan untuk memberikan gambaran atau penjelasan tentang frekuensi dari kelima aktor keterlambatan tersebut . Gambaran atau penjelasan akan disajikan dalam bentuk tabel.

b) Analisis Rangking

Metode analisis ini berguna untuk menentukan rangking para responden dan memberikan prioritas terhadap variabel studi. Setelah pengumpulan data yang diperoleh dari responden, maka hasil data analisis dengan Mean, yang merupakan teknik penjelasan kelompok yang didasar kan dari nilai rata-rata tersebut. Nilai ratarata akan digunakan untuk menentukan faktor-faktor yang sangat berpengaruh dalam keterlambatan pekerjaan

proyek konstruksi. Mean ini didapat dengan cara menjumlahkan data seluruh individu dalam kelompok itu, kemudian dibagi dengan jumlah individu yang ada pada kelompok tersebut. Dari hasil data kuisioner tersebut diperbandingkan sebagai koefisien ranking, kemudian ditentukan ranking dari masingmasing faktor dengan cara mengurutkan nilai Mean dari nilai yang paling tinggi sebagai ranking 1 . 


\section{METODE PENELITIAN}

\section{Lokasi dan Waktu Penelitian}

Lokasi penelitian ini dilakukan pada pekerjaan Rekonstruksi jalan Wolo - Batas Kota Kolaka yang berada di Kabupaten Kolaka Kecamatan Samaturu Desa Liku Desa Kapu panjang pekerjaan 5013 meter (5 kilo meter)

Penelitian ini telah dilaksanakan pada Bulan Desember 2017 sampai dengan Januari 2018. Pelaksanaan penelitian ini dilakukan dengan mengambil data - data baik berupa hasil tertulis maupun wawan cara dengan pihak yang mengetahui tentang proyek tersebut.

\section{Populasi Dan Sampel}

Populasi dalam penelitian ini adalah seluruh karyawan yang ada di PT Putra Bajeng Desa Liku Kecamatan Samaturu Kabupaten Kolaka berjumlah 74 orang.

Sampel merupakan bagian dari jumlah dan karakteristik yang dimiliki oleh populasi tersebut. Dalam penelitian ini mengambil sampel sebesar10\% sehingga ditemukan sampel sebesar dari jumlah keseluruhan populasi adalah 40 karyawan karena jumlah keseluruhan populasi adalah 74 karyawan.

\section{Variabel Penelitian}

Berdasarkan rumusan masalah yang telah dibuat, maka variabel penelitian sebagai berikut :

1) - Waktu perjenis kegiatan baik pelaksanaan maupun rencana.

- Harga rencana dan harga realisasi per item pekerjaan.

2) Volume perjenis kegiatan untuk realisasi dan target waktu yang harus diselesaikan.

3) Faktor cuaca ekstrim, faktor koordiasi antara instansi, faktor keterlambatan pengujian bahan, faktor pengalaman pelaksana dan faktor ketersediaan alat

\section{Sumber Data dan Teknik Pengumpulan Data}

Penelitian ini merupakan studi kasus dengan menggunakan metode survei lapangan untuk mendapatkan data primer. Survei data primer yang dimaksud yaitu dengan melakukan pengamatan langsung di lokasi, mencatat informasi yang ada dari pelaksana proyek, serta melakukan wawancara langsung terhadap pimpinan proyek maupun pelaksana lapangan, alatalat yang digunakan dalam wawancara yaitu buku tulis dan pulpen, digunakan untuk mencatat semua hasil wawancara agar tidak lupa bahkan hilang, sedangkan untuk data sekunder diperoleh dengan cara mengambil data -data proyek dari kontraktok dan konsultan/direksi berupa data gambar kerja, time schedule, spesifikasi teknis, $\mathrm{RAB}$, back up data, laporan mingguan, laporan bulanan dan dokumen lainnya. Kemudian data-data yang telah diperoleh tersebut dianalisis untuk menjawab semua permasalahan yang ada.

\section{Teknik Analisis Data}

Analisis data dilakukan sebagai berikut:

1) Menghitung deviasi menggunakan persamaan 2.1. rencana dan realisasi dengan mengetahui bobot, harga per item pekerjaan kemudian dibagi dengan harga keseluruhan dikali seratus persen, untuk mendapatkan nilai deviasi, realisasi kurang rencana.

2) Menghitung efektifitas waktu pekerjaan, dengan mengetahui volume setiap bulan item pekerjaan kemudian dianalisis menggunakan persamaan 2.1 dan persamaan 2.2, 2.3, 2.4

3) Menganalisis faktor-faktor yang mempengaruhi efektifitas pelaksanaan menggunakan data kuisioner kemudian menggunakan aplikasi SPSS untuk pengolahan data kuisioner untuk mengetahui frekuensi dan metode mean rank untuk mengetahui faktor mana yang 
paling berpengaruh terhadap pelaksanaan.

\section{Definisi Operasional}

Definisi operasional dimaksudkan untuk menghindari kesalah pahaman dan perbedaan penafsiran yang berkaitan dengan istilah - istilah dalam judul penelitian. Sesuai dengan judul penelitian ini "Efektifitan Waktu Pelaksanaan Pekerjaan Rekonstruksi Jalan Wolo - Batas Kota Kolaka - Rate Rate". Maka definisi operasional yang perlu dijelaskan, yaitu :

1) Efektifitas adalah perbandingan antara input dan output dalam berbagai

aktifitas kegiatan sampai dengan pe ncapaian tujuan terpenuhi yang bisa dari berupa banyaknya kuantitas dan kualitas hasil kerja, maupun batas waktu yang sudah ditetapkan atau di targetkan sebelumnya

2) Deviasi adalah penyimpangan terhadap waktu tercapainya progres yang direncanakan.

3) Faktor cuaca ekstrim adalah keadaan dimana dalam pelaksanaan pekerjaan proyek terjadi hujan sehingga pekerjaan terhenti

4) Faktor koordinasi antara instansi adalah dimana dalam melakukan kordinasi dengan pihak PLN kontraktor tidak terlebih dahulu melakukan kordinasi ke pihak PLN daerah setempat, tapi langsung kepusat yang seharusnya kordinasi kedaerah dulu hal itulah yang menyebabkan sehingga beberapa tiang listrik terlambat di pindahkan.

5) Faktor keterlambatan pengujian bahan adalah bahan yang tersedia sudah siap diuji tetapi pihak kontraktor menunda-nunda ketika akan melakukan pengujian sehingga aggregat yang seharusnya sudah siap dihampar dilapangan menjadi tertunda yang menyebabkan keterlambatan.

6) Faktor pengalaman pelaksana adalah pihak kontraktor rata-rata belum mempunyai pengalaman dalam mengerjakan proyek APBN sehingga setiap melakukan pekerjaan mereka kesulitan dalam menentukan pekerjaan yang mana yang harus dikerjakan lebih awal.

7) Faktor ketersediaan alat adalah setiap melakukan pekerjaan, adanya alat yang digunakan dalam hari yang sama diproyek yang lain sehingga waktu pekerjaan yang ditargetkan menjadi terlambat. 


\section{Konsep Operasional}

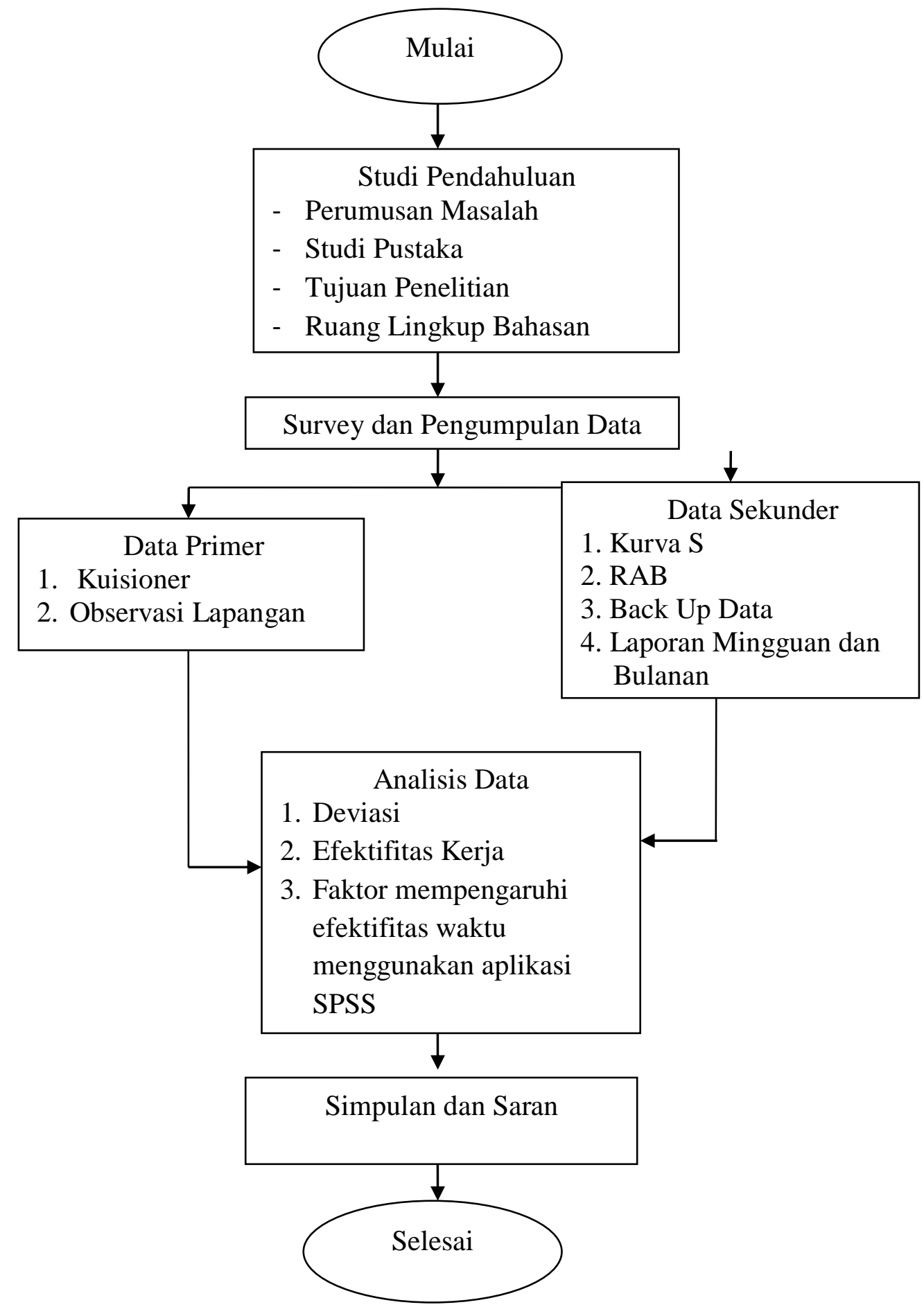




\section{HASIL DAN PEMBAHASAN}

\section{Analisa Rencana dan Realisasi Pada}

Pekerjaan Rekonstruksi Jalan Wolo -

Batas Kota Kolaka - Rate Rate

Analisa realisasi pekerjaan dilakukan agar mengentahui deviasi antara rencana dan realisasi dan bagaimana cara mendapatkan nilai realisasi, pada Skripsi ini penulis akan membahas mengenai progres tercapainya atau realisasi pekerjaan dan deviasi perbulan pada pekerjaan Rekonstruksi Jalan Wolo - Batas Kota Kolaka - Rate Rate. Pada Bulan Februari, Maret April, Mei Juni, Juli dan Agustus yang mempunyai bobot sampai selesainya kontrak kerja hanya $44,621 \%$ dikerjakan selama 210 hari.

Analisis Rencana, Realisasi dan Deviasi

Tabel 4.1 Rencana, Realisasi dan Deviasi

\begin{tabular}{|c|c|c|c|}
\hline Bulan & $\begin{array}{c}\text { Rencana } \\
(\%)\end{array}$ & $\begin{array}{c}\text { Realisasi } \\
(\%)\end{array}$ & $\begin{array}{c}\text { Deviasi } \\
(\%)\end{array}$ \\
\hline $\begin{array}{c}\text { Februari } \\
2017\end{array}$ & 0,412 & 0,187 & $-0,225$ \\
\hline $\begin{array}{c}\text { Maret } \\
2017\end{array}$ & 9,470 & 4,615 & $-4,855$ \\
\hline $\begin{array}{c}\text { April } \\
2017\end{array}$ & 31,488 & 21,370 & $-10,118$ \\
\hline Mei & 52,380 & 31,774 & $-20,606$ \\
2017 & & & \\
\hline Juni & 68,924 & 31,565 & $-37,359$ \\
2017 & & & \\
\hline Juli & 92,038 & 34,927 & $-57,111$ \\
\hline 2017 & & & \\
\hline $\begin{array}{c}\text { Agustus } \\
2017\end{array}$ & 100 & 44,621 & $-55,379$ \\
\hline Sumber & & & \\
\hline
\end{tabular}

Sumber : Hasil Olah Data 2018

Berdasarkan data, jumlah anggaran untuk rekonstruksi jalan wolo - batas kota kolaka - rate rate adalah Rp 27.917.225.449,37 setelah PPN Rp
25.379.295.863,06 Pada Bulan Februari pekerjaan berupa Divisi 1 Umum, sehingga perhitungan bobot adalah sebagai berikut :

$$
\begin{aligned}
\text { Bobot } & =\frac{47.360 .000}{25.379 .295 .863_{,} 06} \times 100 \% \\
& =0,187 \%
\end{aligned}
$$

Rencana $=0,412 \%$

Realisasi $=0,187 \%$

Deviasi $=-0,225$

Pada Bulan Juni, Juli dan Agustus terjadi adendum sehingga jumlah anggaran rekonstruksi jalan wolo - batas kota kolaka - rate rate adalah $\mathrm{Rp}$ 29.795.345.674,39 setelah PPN Rp 27.086.677.885,81. Sehingga perhitungan bobot pada bulan juni adalah sebagai berikut :

$$
\begin{aligned}
: \text { Bobot } & =\frac{8.549 .874 .372,28}{27.086 .677 .885,81} \times 100 \% \\
& =31,565 \%
\end{aligned}
$$

Rencana $=68,924 \%$

Realisasi $=31,565 \%$

Deviasi $=-37,359$

\section{Analisis Efektifitas Waktu \\ Pekerjaan Agregat Kelas B}

Pada pelaksanaan pekerjaan agregat kelas B dikerjakan pada bulan April bulan Agustus dimana jenis kegiatan ini adalah pekerjaan pelebaran perkerasan dan bahu jalan dan pekerjaan perkerasan berbutir, untuk mengetahui waktu efektifitas kerja setiap bulan terlebih dahulu mengetahui volume pekerjaan tersebut dimana vulume pada bulan April pelebaran perkerasan dan bahu jalan adalah $1270 \mathrm{~m}^{3}$, pekerjaan perkerasan berbutir $1890 \mathrm{~m}^{3}$, bulan Mei, Juni, Juli dan Agustus pelebaran perkerasan dan bahu jalan adalah 3336 $\mathrm{m}^{3}$, pekerjaan perkerasan berbutir 6269 $\mathrm{m}^{3}$,

Pada pekerjaan aggregat kelas B merupakan pekerjaan pondasi lapis bawah, sehingga alat-alat yang di gunakan adalah :

1) Crusher : :1 unit

2) Dump Truck $: 8$ unit kapasitas 10 ton

5 unit kapasitas 5 ton

3) Motor Greder : : 1 unit

4) Tandem : :1 unit 
Itulah alat-alat yang di gunakan pada pekerjaan aggregat kelas $\mathrm{B}$, kapasitas cold bin $4 \mathrm{~m}^{3}$ dan kapasitas crusher $200 \mathrm{~m}^{3}$ perhari sehingga dump truck yang digunakan sudah mampu melayani 1 unit crusher dengan kapasitas $200 \mathrm{~m}^{3}$

Berikut Spesifikasi pekerjaan kelas B adalah :

1) Volume Pekerjaan $\quad: 1270 \mathrm{~m}^{3}$

2) Panjang pekerjaan : $1270: 6,5:$ $0,20=976,92 \mathrm{~m}$

3) Lebar pekerjaan : widenning 6,5 meter kiri/kanan

Full deap

11 meter

4) Tebal pekerjaan :0,20 meter

5) Berat isi : 1,3

Kebutuhan Tonase Aggregat Kelas B

$=$ Panjang $\mathrm{x}$ Lebar $\mathrm{x}$ Tebal $\mathrm{x}$ Berat isi

$=976,92 \times 6,5 \times 0,20 \times 1,3$

$=1650,99$ ton

Jadi dalam satu bulan pekerjaan aggregat kelas $\mathrm{B}$ membutuhkan tonase 1650,99 ton

\section{Efektifitas Waktu Pekerjaan Aggregat Kelas B}

Kapasitas Crusher : $200 \mathrm{~m}^{3}$ x 6,5 x 0,20 $\mathrm{x} 1,3=338$ ton $=338.000 \mathrm{~kg}$

Waktu lama mixing : kelas B 2 fraksi, 5 menit

Waktu efektif kerja/hari : 8 jam

Tonase yang di butuhkan dalam 1 bulan $=1650,99$ ton

Kapasitas crusher/hari

$=338$ ton

$\frac{1650,99}{338}=5$ hari

\section{Pekerjaan Agregat Kelas A}

Pada pelaksanaan pekerjaan agregat kelas A dikerjakan pada bulan Mei - bulan Agustus dimana jenis kegiatan ini adalah pekerjaan pelebaran perkerasan dan bahu jalan dan pekerjaan perkerasan berbutir, untuk mengetahui waktu efektifitas kerja setiap bulan terlebih dahulu mengetahui volume pekerjaan tersebut dimana vulume pada bulan Mei pelebaran perkerasan dan bahu jalan adalah 980,26 $\mathrm{m}^{3}$, bulan Juni pelebaran perkerasan dan bahu jalan adalah $315 \mathrm{~m}^{3}$, pekerjaan perkerasan berbutir 980,26 $\mathrm{m}^{3}$, Juli pelebaran perkerasan dan bahu jalan adalah $1021 \mathrm{~m}^{3}$, pekerjaan perkerasan berbutir $3100,26 \mathrm{~m}^{3}$, dan Agustus pelebaran perkerasan dan bahu jalan adalah $1721 \mathrm{~m}^{3}$, pekerjaan perkerasan berbutir $540026 \mathrm{~m}^{3}$,

Pada pekerjaan aggregat kelas A merupakan pekerjaan pondasi lapis bawah, sehingga alat-alat yang di gunakan adalah :
1) Crusher
$: 1$ unit
2) Dump Truck
: 8 unit kapasitas 10 ton

5 unit kapasitas 5 ton
3) Motor Greder
$: 1$ unit
4) Tandem
$: 1$ unit

Itulah alat-alat yang di gunakan pada pekerjaan aggregat kelas A, kapasitas cold bin $4 \mathrm{~m}^{3}$ dan kapasitas crusher $200 \mathrm{~m}^{3}$ perhari sehingga dump truck yang digunakan sudah mampu melayani 1 unit crusher dengan kapasitas $200 \mathrm{~m}^{3}$

Berikut Spesifikasi pekerjaan kelas A adalah :
1) Volume Pekerjaan
: $980,26 \mathrm{~m}^{3}$
2) Panjang pekerjaan
: 980,26: 11 :
$0,20=445,57 \mathrm{~m}$
3) Lebar pekerjaan
6,5 meter kiri/kanan
: widenning

Full deap

11 meter

4) Tebal pekerjaan

5) Berat isi

: 0,20 meter

$: 1,3$

\section{Kebutuhan Tonase Aggregat Kelas A}

$$
\begin{aligned}
& =\text { Panjang } \mathrm{x} \text { Lebar } \mathrm{x} \text { Tebal } \mathrm{x} \text { Berat isi } \\
& =445,57 \times 11 \times 0,20 \times 1,3 \\
& =1274,33 \text { ton }
\end{aligned}
$$

Jadi dalam satu bulan pekerjaan aggregat kelas A membutuhkan tonase 1274,33 ton 
Efektifitas Waktu Pekerjaan Aggregat Kelas A

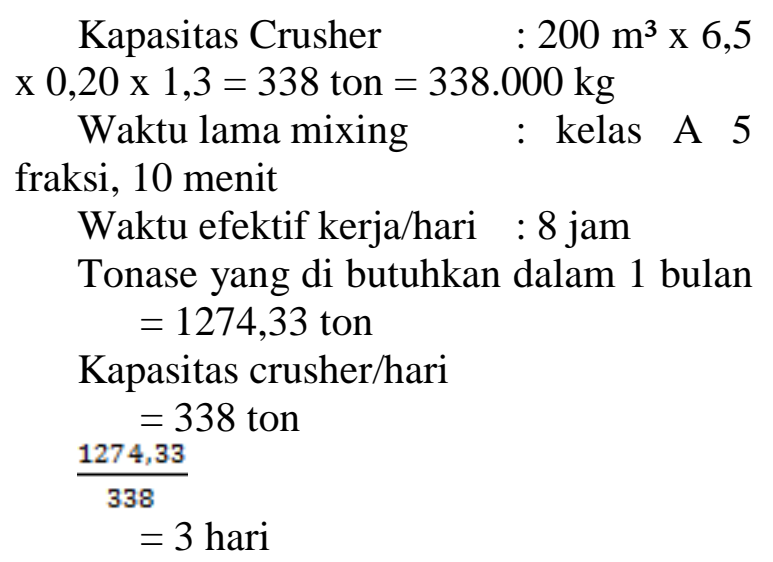

\section{Pekerjaan Pengaspalan AC-BC}

Pada analisa efektifitas ini penulis akan membahas mengenai pekerjaan pengaspa lan AC-BC (lapis antara).

Pada pekerjaan pengaspalan merupakan pekerjan pengaspalan lapis antara sehingga alat-alat yang di gunakan adalah:

1. AMP (Asphalt Mixing Plant) $=1$ unit

2. Wheel Loader

$$
=1 \text { unit }
$$

3. Dump Truck

$=8$ unit

kapasitas 10 ton
4. Asphalt Finisher
$=1$ unit
5. Tandem Roller
$=1$ unit
6. TR ( Tire Roller)
$=1$ unit

Itulah alat-alat yang digunakan pada pekerjaan pengaspalan, wheel loader di gunakan 1 karena muatan bucket loader $\pm 1,5 \mathrm{~m} 3$ sudah mampu melayani 4 cold bin dengan nilai buka AMP $700 \mathrm{~kg} / 1,37$ menit dan menurut data yang ada bin 1 adalah abu batu, bin 2 abu batu, bin 3 medium, bin 4 CA.

Di ketahui bahwa split yag di butuhkan AMP untuk mixing setiap 1,37 menit pada bin 1 adalah $0,26285 \mathrm{~m} 3$, bin 3 adalah $0,2050 \mathrm{~m} 3$, bin 4 adalah $0,00685 \mathrm{~m}_{3}$, dengan kapasitas cold bin sebesar $\pm 2,5$ kubik dan bucket loader adalah 1,25 m3, jadi nilai pengeluaran tiap bin masih jauh di bandingkan nilai kapasita bucket wheel loader.

\section{Pekerjaan Pengaspalan AC-BC Bulan Agustus 2017}

Dikarenakan bulan Juli tidak ada peker jaan pengaspalan sehingga pekerjaan pengaspalan AC-BC dilakukan pada bulan agustus, adapun spesifikasi pekerjaan pengaspalan adalah:

Volume Pekerjaan $\quad=1228,28 \mathrm{~m}^{3}$

Panjang pekerjaan $\quad=1228,28: 7$

: $0,06=2924,48 \mathrm{~m}$

Lebar pekerjaan $\quad=7 \mathrm{~m}$

Tebal pekerjaan $\quad=0,06 \mathrm{~m}$

Berat jenis aspal AC-BC $=2,26$

\section{Kebutuhan Tonase Aspal AC-BC}

Kebutuhan tonasenya adalah :

$=$ panjang $\mathrm{x}$ lebar $\mathrm{x}$ tebal $\mathrm{x}$ berat jenis

$=2924,48 \mathrm{~m} \times 7 \mathrm{~m} \times 0,06 \mathrm{~m} \times 2,26$

$=2775,92$ ton

Jadi dalam satu bulan pekerjaan pengaspalan AC-BC membutuhkan tonase 2775,92 ton.

\section{Efektifitas Waktu Pekerjaan Aspal AC- BC \\ Tehnik Mandiri)-800 (PT Putra} Bajeng AMP yang digunakan adalah merek AMP (Aneka dengan kapasitas satu kali buka $700 \mathrm{~kg} /$ mixing sehingga :

Kapsitas AMP sekali buka $=700 \mathrm{~kg}$

Waktu lama mixing $\quad= \pm 1,37$ menit

Waktu Efektif Kerja $\quad=7$ jam karena waktu panas AMP selama 3 jam mulai jam 6 jam 9 pagi

Sehingga kapasitas AMPnya adalah

Jika $700 \mathrm{~kg}=1,37$ menit

Maka $700 \times 7=4900 \mathrm{~kg}=1 \mathrm{jam}$

Waktu efektif kerja/hari $=7$ jam

Maka $4900 \times 7=34300 \mathrm{~kg}=34,3$ ton $/ 7$ jam

Tonase yang di butuhkan dalam 1 bulan $=2775,92$ ton

Kapasitas AMP/hari

$$
=34,3 \text { ton } \mathrm{x} 7 \mathrm{jam}=240,1 \text { ton }
$$

2775,92 ton

$$
=12 \text { hari }
$$

240,1 ton

Sehingga efektifitas waktu kerja untuk pekerjaan pengaspalan untuk bulan Agustus 
adalah target 12 hari realisasi 27 hari kerja sedangkan untuk nilai efektifitasnya adalah 0,4

\section{Analisa Faktor Yang Mempengaruhi Efektifitas Pelaksanaan}

Dari hasil data kusioner, data ini dibagi menjadi lima rangking jenis faktor yang mempengaruhi efektifitas pelaksanaan yaitu faktor cuaca ekstrim, faktor kordinasi antara instansi, faktor keterlambatan pengujian bahan, faktor pengalaman pelaksana dan faktor ketersediaan alat. Dari kelima faktor tersebut data kuisioner kemudian di olah menggunakan SPSS untuk mengetahui frekuensi setelah itu dianalisis menggunakan metode mean rank untuk mengetahui dari kelima faktor tersebut, faktor mana yang sangat berpengaruh terhadap pelaksanaan.

Tabel 4.2 Frekuensi Faktor Yang Mempengaruhi Efektifitas

\begin{tabular}{|l|l|l|l|l|l|}
\hline & $\begin{array}{l}\text { X1 } \\
(\%)\end{array}$ & $\begin{array}{l}\text { X2 } \\
(\%)\end{array}$ & $\begin{array}{l}\text { X3 } \\
(\%)\end{array}$ & $\begin{array}{l}\text { X4 } \\
(\%)\end{array}$ & $\begin{array}{l}\text { X5 } \\
(\%)\end{array}$ \\
\hline $\begin{array}{l}\text { Sangat } \\
\text { Tidak } \\
\text { Berpenga } \\
\text { ruh }\end{array}$ & 2.5 & 2.5 & 0 & 0 & 0 \\
\hline $\begin{array}{l}\text { Tidak } \\
\text { Berpenga } \\
\text { ruh }\end{array}$ & 0 & 3.0 & 0 & 0 & 0 \\
\hline $\begin{array}{l}\text { Cukup } \\
\text { Berpengar } \\
\text { uh }\end{array}$ & 12.5 & 27.5 & 15.0 & 32.5 & 0 \\
\hline $\begin{array}{l}\text { Berpenga } \\
\text { ruh }\end{array}$ & 35.5 & 37.5 & 47.5 & 42.5 & 55.0 \\
\hline $\begin{array}{l}\text { Sangat } \\
\text { Berpenga } \\
\text { ruh }\end{array}$ & 50.0 & 2.5 & 37.5 & 25.0 & 45.0 \\
\hline \multicolumn{1}{|c|}{ Total } & 100 & 100 & 100 & $\begin{array}{l}100 \\
.0\end{array}$ & $\begin{array}{l}100 \\
.0\end{array}$ \\
\hline
\end{tabular}

Sumber: Hasil Olah Data SPSS 2018

Berdasarkan Gambar 4.4 terlihat bahwa nilai persen yang sangat tinggi yaitu faktor cuaca ekstrim sangat berpengaruh berada pada nilai $50 \%$, Faktor kordinasi antara instansi berpengaruh berada pada nilai 37.5
$\%$, faktor keterlambatan pengujian berpeng aruh bahan berada pada nilai $47.5 \%$, faktor pengalaman pelaksana berpengaruh berada pada nilai 42.5 , faktor ketersediaan alat berpengaruh $55.0 \%$

Tabel 4.3 Analisis Mean Rank

\begin{tabular}{|l|c|c|c|}
\hline $\begin{array}{l}\text { Faktor Yang } \\
\text { Mempengaruhi } \\
\text { Efektifitas }\end{array}$ & $\begin{array}{l}\text { Mean } \\
\text { Rank }\end{array}$ & \multicolumn{2}{|l|}{ Test Statistics } \\
\hline Cuaca Ekstrim & 3.0 & $\mathrm{~N}$ & 5 \\
\hline $\begin{array}{l}\text { kordinasi } \\
\text { Antara Instansi }\end{array}$ & 3.30 & $\begin{array}{c}\text { Kendall } \\
\text { 's }\end{array}$ & 014 \\
\hline $\begin{array}{l}\text { Keterlambatan } \\
\text { Pengujian } \\
\text { Bahan }\end{array}$ & 2.90 & $\begin{array}{c}\text { Chi- } \\
\text { Square }\end{array}$ & 282 \\
\hline $\begin{array}{l}\text { Pengalaman } \\
\text { Pelaksana }\end{array}$ & 2.90 & df & 4 \\
\hline $\begin{array}{l}\text { Ketersediaan } \\
\text { Alat }\end{array}$ & 2.90 & $\begin{array}{l}\text { Asymp. } \\
\text { Sig. }\end{array}$ & 991 \\
\hline
\end{tabular}

Sumber: Hasil Olah Data SPSS 2018

Berdasarkan gambar 4.5 dari hasil analisis mean rank terlihat bahwa yang sangat berpengaruh yaitu kordinasi antara instansi dengan nilai 3.30 kemudian cuaca ekstrim dengan nilai 3.0, keterlambatan pengujian bahan, pengalaman pelaksana, ketersediaan alat mempunyai nilai yang sama yaitu 2.90. Sehingga faktor - faktor yang mempengaruhi efektifitas pelaksanaan pekerjaan yaitu kordinasi antara instansi.

\section{SIMPULAN DAN SARAN}

\section{Simpulan}

1) Pada Bulan Februari - Agustus rencana dan realisasi tidak sesuai dimana deviasi keterlambatan paling besar terjadi pada bulan Juli yaitu $57,111 \%$

2) Nilai efektifitas waktu pekerjaan agregat kelas B Bulan April Agustus rata - rata 0,79. Pekerjaan agregat kelas A Bulan Mei Agustus rata - rata 0,39. Pekerjaan 
pengaspalan AC-BC pada bulan Agustus 0,4

3) Faktor yang mempengaruhi efektifitas pelaksanaan pekerjaan adalah faktor cuaca koordinasi antara instansi 3,30, faktor cuaca ekstrim 3,0, faktor keterlambatan pengujian bahan 2,90, faktor pengalaman pelaksana 2,90, faktor ketersediaan alat 2,90

\section{Saran}

1) Berdasarkan data di atas banyak sekali waktu yang tersisa di setaip bulan pekerjaan, sehingga sebaiknya pengerjaan di kejar sehingga bisa memperoleh keuntungan.

2) Kordinasi antara instansi lebih ditingkatkan lagi agar pekerjaan yang terhambat dapat terselesaikan lebih cepat.

\section{DAFTAR PUSTAKA}

Abrar, 2009. "Manajemen Proyek",

Yogyakarta.

Anonim, 2013. “Analisa Kinerja Proyek

Infrastruktur:.

Barrie, D.S,1995."Manajemen Konstruksi

Profesional”,Jakarta: Penerbit Erlangga

Djojowirono. 2005. "Manajemen

Konstruksi Edisi Keempat, Teknik Sipil

UGM, Yogyakarta

Mahmudi, 2005 "Manajemen Kinerja

Sektor Publik". Yogyakarta.

Sriyatno, Edi. 2005 "Efisiensi Dan Efektiitas Pemeliharaan Jalan Secara Swakelola", Surakarta

Soeharto, Imam.1999.“Manajemen Proyek

(Dari Konseptual Sampai Operasional)

Jilid 1". Jakarta:Erlangga 